The Yale Library of Military History

Donald Kagan and Frederick Kagan, Series Editors 
This page intentionally left blank 


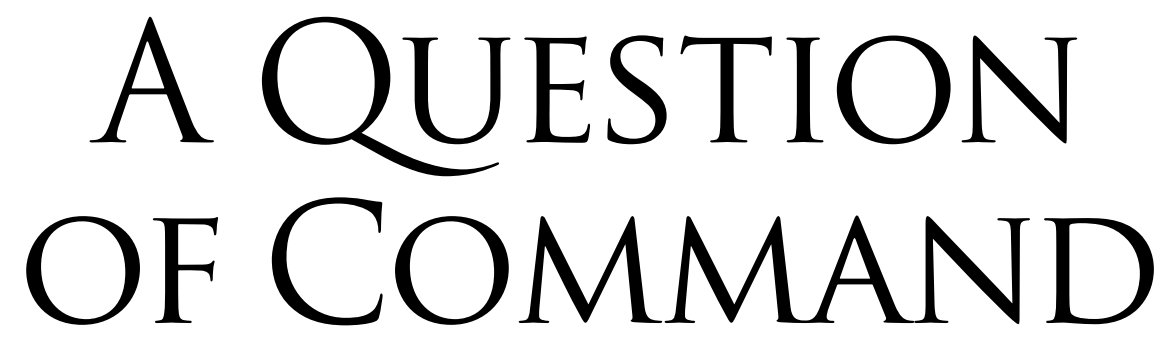

Counterinsurgency from

the Civil War to Iraq

\section{Mark Moyar}

Foreword by Donald Kagan

and Frederick Kagan

Yale University Press New Haven \& London 
Published with assistance from the Kingsley Trust Association Publication Fund established by the Scroll and Key Society of Yale College.

Copyright (C) 2009 by Mark Moyar.

All rights reserved.

This book may not be reproduced, in whole or in part, including illustrations, in any form

(beyond that copying permitted by Sections 107 and 108 of the U.S. Copyright Law and except by reviewers for the public press), without written permission from the publishers.

Set in Minion type by Tseng Information Systems, Inc.

Printed in the United States of America.

\section{Library of Congress Cataloging-in-Publication Data}

Moyar, Mark, 1971-

A question of command : counterinsurgency from the Civil War to Iraq /

Mark Moyar ; foreword by Donald Kagan and Frederick Kagan.

p. cm. - (Yale library of military history)

Includes bibliographical references and index.

ISBN 978-0-300-15276-o (alk. paper)

1. Counterinsurgency-History. 2. Counterinsurgency-United States-History.

3. Command of troops. I. Title.

U241.M69 2009

355.02 '180973-dc22

2009013368

A catalogue record for this book is available from the British Library.

This paper meets the requirements of ANSI/NISO Z39.48-1992 (Permanence of Paper).

10987654321 
To the armed forces of the United States, sentinels on the parapets of freedom 
This page intentionally left blank 